\title{
Holy Places that Have Played a Role in the Urban Evolution of Damascus
}

\author{
GHALEB ANABSEH ${ }^{1}$
}

\begin{abstract}
This study describes some of the shrines that contributed to the urban development of Damascus from the emergence of Islam to the middle ages. It also discusses the connection between the existence of holy places which attract pilgrims for religious and spiritual reasons, and the expansion of cities. The main sources for this study are writings in the 'virtues of the Holy Land' genre, augmented by the publications on this subject by Orientalists and Arab scholars.
\end{abstract}

Keywords: Damascus, holy places, mosque, tomb, urbanisation

Many cities, in the Muslim world and elsewhere, were built around shrines, or expanded because of the importance that people attached to them. Occasionally it happened that a number of shrines were established at a particular location before the founding of a city there, while at other times the construction of the shrines and the evolution of the city went hand-inhand, more-or-less, that is, neighbourhoods in the city expanded because they were in the vicinity of shrines, be they mosques, saints' tombs or religious schools.

It is a well-known fact that urban growth or expansion of any city is usually associated quite closely with the expansion of the available land. Anyone who studies the urban extension of Damascus in relation to that of other Muslim and non-Muslim cities faces numerous questions, since the case of Damascus differs from that of other cities which Muslims helped to build for whatever reasons, be they political, administrative or religious.

Since, Damascus was first conquered by the Muslims (in $635 \mathrm{CE}$ ), its residential expansion did not proceed according to the same standards as in other Muslim cities. Instead, its expansion occurred in a haphazard fashion (Kharisat 1992). Since its afore-mentioned conquest Damascus had an oval shape, surrounded by walls with gates. After the conquest many of its houses became abandoned. It is the prevailing opinion that the city was not attractive at the time and so very few people came to settle in it. Historical sources have very little to say about the expansion of residential houses in the city, with the exception of the mention of a few of the Prophet's companions who desired to reside there. This is the very first indication of the city's residential features (al-Nu`aymi 1990). Damascus retained its oval stretched-out shape until a relatively late period. The greater part of the city was given over to religious institutions, religious schools and shrines. The existence of the Umayyad mosque certainly had a role in the maintenance of religious schools there.

It is noted that in the Aramaean period the city's core was located on an elevation at the centre of the Old City, at an altitude of a few meters above the level of the rest of the city. All that is known of Damascus in antiquity is that it was in reality a village in the early Roman period. The Romans made some changes, so that the ancient part of the city came to be contained in one of the four quarters into which it was divided by the Cardo and the Decumanus, when it received the shape of an elongated oval consisting of four parts. That was in the Roman period, and after the Muslims captured Damascus they introduced numerous prominent changes in the

${ }^{1}$ Ghaleb Anabseh, Ph.D., Senior Lecturer at the Dept. of Arabic Language and Literature, Beit Berl Academic College, BEIT BERL 44905, Israel, email: jaleb.anavsa@beitberl.ac.il. 
city's structure (Sauvaget 1934). A quick perusal of the city's evolution from the Umayyad period, in which the Muslims ruled Damascus, shows that the new rulers built two new structures, namely the Umayyad Mosque and the House of the Caliphate, known as the Green Palace, to the south of the mosque. The Caliph Mu awiya ibn Abi Sufyan (d. 680 CE) renewed construction in the city on the model of the previous period, before the Muslim conquest. Around the two afore-mentioned buildings are the homes of Arabs and Muslims (Sauvaget 1934). To this must be added the numerous houses and palaces constructed by the Umayyad Caliphs in various parts of the city, especially during the reign of `Abd al-Malik b. Marwan.

In the Abbasid period the city's architectural landscape changed relatively little, perhaps due to political considerations, or perhaps because of the fact that the centre of the Caliphate moved from Damascus to Baghdad, or again due to other factors, including the fact that many famous houses and palaces from the Umayyad period were destroyed. However, this did not prevent them from rebuilding inside the city, or from reconstructing the wall that had been destroyed. In fact, a number of Abbasid Caliphs, such as al-Mansur and al-Mahdi, built quite a lot in Damascus, and renewed some building, as reported in a number of ancient historical and geographical sources (Kharisat 1992). The Fatimid period was not very significant in the urban growth of Damascus. When the Fatimids took over the city in the year $907 \mathrm{CE}$ the city in fact began to shrink back within its walls, after it previously experienced a period of relative expansion beyond the walls. The reduction in the city's size was due to internal strife, which caused many people to leave Damascus and settle elsewhere. Many houses, in fact entire neighbourhoods, were destroyed, among them were some mosques. The reason for this was that the governors changed frequently and their soldiers mistreated the local populace. The most prominent such event was perhaps the fire which consumed the Umayyad Mosque in the year $1068 \mathrm{CE}$, which exacerbated the people's confusion.

As for the Mamluk period, this was a time in which numerous holy shrines, mosques and religious schools were constructed in Damascus. This may also have affected the city's topographical expansion and the expansion of construction. In the Ottoman period a number of factors affected the city's development, including the Syrian pilgrimage caravan whose point of departure was Damascus and which had considerable economic influence on the local citizenry, who provided services to the many pilgrims who came to the city in order to join the caravan on its journey to the holy cities in the Hijaz. A historical-topographical overview of Damascus reveals that this is a city that consists of a collection of many villages that grew and expanded towards the city centre as time went on, in contrast to the city of al-Ghuta, which has retained its beautiful gardens and fields despite the distinct geographical and human elements of which it is composed. Damascus, unlike the latter, did not evolve independently of its historical and political circumstances; in other words, it evolved not only from the centre but from various different directions, so that various population centres came to be joined to the city centre.

In a study of this kind it is necessary to take into account also modern studies, in the West and the Arab world, that describe Muslim cities in various time periods. These scholars found that the social and physical structure of Muslim cities reflected the ideals of social life according to Islam. Two studies especially deserve mention, J. Sauvaget's pioneering study of urban life in the Muslim world and I. Lapidus' study of the major cities in the Mamluk period (Sauvaget 1934). Obviously, there exists a direct and sometimes an indirect connection between urban expansion and the presence of shrines in the vicinity. Numerous Muslim villages and towns were built around shrines of well-known Islamic figures, in addition to the religious and spiritual importance of these shrines. Moreover, religious factors, in the form of the construction of mosques, Sufi cloisters, mausoleum, religious schools and the homes of prominent religious and historical figures, brought about a kind of 'urban agglomeration' that helped Damascus expand geographically. 
Historically, spiritual or religious background often constitute the primary starting point of such an agglomeration motivated by belief in the efficacy of a holy shrine in bringing about recovery from illness, divine intercession following prayer there, and the like. Such beliefs provided the main stimulus for the establishment and development of shrines. Certainly such beliefs cannot be adverse to the establishment of holy places. The existence of different types of holy places seems to be the second point of the attraction to such urban agglomeration. Perhaps the most important issue in this respect is the question of how such places succeed in attracting pilgrims and making them perform the various official and unofficial rites associated with them. In a sense, such pilgrims are the 'consumers' of religious or spiritual needs. The second point of attraction carries more weight as it fits to fact that many religious scholars grew up in important Muslim cities, due to the fact that they contained religious institutions such as schools and mosques hence, attracted people of different cultural background.

In addition, various types of holy places in any region of the world can be classified into three levels in terms of importance. Thus, for example, the shrines inside a city (including, among others, Damascus, Aleppo and Homs) are usually of the greatest importance, those next to the city are of the second degree of importance, while those in the surrounding villages are of the third degree of importance. With respect to the previous point, a number of examples of shrines that played a role in the urban development of Damascus need to be provided. This city, as is well known, is surrounded by holy places constructed in various periods of its history which lead to its expansion. This is especially true of the Mamluk and Ottoman periods. Some of these places are discussed as follow.

\section{The Mosque of al-Qadam or al-Aqdam}

This mosque is located to the south of the city. According to a tradition the mosque is located over a print of Moses' foot (qadam in Arabic), although this is disputed in other traditions, as well as among historians and the authors of books of 'virtues' and pilgrimage sites in Damascus and Syria (Sadan 1981; al-Harawi 1953; Ibn Tulun MS). The mosque is located south of the city of Damascus, east of al-Qubaybat, at the head of the al-Hasa field, near the place of that name. A village named 'al-Qadam' arose next to the mosque and eventually became a quarter of Damascus. It is to be noted that neither Islamic nor Western studies show the place on their maps; rather, they merely mention the fact that it is located south of Damascus. The following are some of the 'virtues' and other books that mention the location of the al-Qadam Mosque and/or the village of al-Qadam (al-Aqdam): Ibn `Asakir's Tarikh Madinat Dimashq, al-'Adwi's (d. 1032/1622) Kitab al-Ziyarat bi Dimashq, and Ibn `Abd al-Razzaq al-Dimashqi's (d. 1140/1727) Hada'iq al-In `am fi Fadail al-Sham (Ibn `Asakir 1995; Ibn `Abd al-Razzaq 1995; al-`Adawi 1956; Meri 2001). According to some studies, as in Meri's, for example, the quarters into which Damascus is divided are noted. This is also the case in some 'virtues' books, such as Ibn alHawrani's (d. 970/1562) Al-Isharat ila Amakin al-Ziyarat and Ibn `Abd al-Razzaq al-Dimashqi's Hada'iq al-In 'am fi Fadail al-Sham. Al-Nu`aymi (d. 928/1521) mentions the al-Qadam Mosque several times in his Al-Dāris fi Tārīkh al-Madāris. More importantly, he mentions many educated men who were buried in that mosque, which seems to have had a cemetery associated with it, in which notable pious people were buried (al-Nu`aymi 1990). Eventually the mosque evolved into a quarter of the city of Damascus.

\section{The Tomb of `Atika Daughter of Yazid B. Mu`awiya (D. 123/749)}

This shrine has also become part of a residential neighbourhood of the city. It is known that 'Atika, who lived in the Umayyad period, had a palace outside the Jabiya Gate, at a place called 'al-Mahalla' (literally: 'the place') and which was later given her name, by command of her aforementioned husband. It is this 'mahalla' in which the palace was built, and where the tomb is 
located. Now while it is difficult to determine precisely the city's extent in the Umayyad period, what is clear is that it expanded to the south-west relatively more than in other directions. During the Mamluk and Ottoman periods the area in which 'Atika's tomb is located evolved into a residential neighbourhood that is known today by the name Qabr 'Atika ('Atika's Tomb'). Geographically, 'Atika's Tomb is located in the southern part of Damascus, between the Musalla and the Sanāniyya gates. Its location is an evidence of the influence that shrines had on the expansion of the residential neighbourhoods of Damascus (Al-Nu aymī 1990; al-Aybash, alShihabi 1996; Kharisat 1996).

\section{The Abu Salih Mosque in the Salihiyya Quarter}

It is a large neighbourhood in Damascus that was built in the wake of the Crusader occupation of Jerusalem, when many Muslim scholars left that city and moved to Damascus, among them Abu 'Umar b. Qadama al-Maqdisi (d. 607/1210), who settled with his disciples in the Abu Salih Mosque, outside Bab Sharqi (the East Gate), also called al-Salihiyya, after the mosque. Ibn Tulun (d. 953/1546) in his Al-Qalaid al-Jawhariyya fi Tarikh al-Salihiyya states: "It is said that because those who laid its foundations were in the Abu Salih mosque it was ascribed to it". Evidence for this can be found in Ibn `Abd al-Razzaq al-Dimashqi's (d. 1140/1727) book Hadaiq al-In `am fi Fadail al-Sham, in which the author writes: "Abu 'Umar says: We are called after the Abu Salih Mosque because we are devout". This neighbourhood has, since its founding in the Ayyubid period, been the site of numerous religious schools. It underwent an urban revival and expansion from the Mamluk to the Ottoman period. It is located in the northern part of the city. The mosque ascribed to Abu Salih is mentioned in al-Nu'aymi's Al-Daris fi Tarikh al-Madaris: "A mosque to the south of the Eastern Gate, near al-Khandaq" (al-Nu`aymi 1990; al-Baarawi 1998). However, the afore-mentioned Abu 'Umar was definitely buried at the foot of Mt. Qasyun.

\section{Mahallat al-Shaykh Arslan al-Dimashqi (d. 550/1155)}

This mahalla was named after the sufi shaykh Arslan al-Dimashqi. His shrine in Damascus is a popular pilgrim destination. There is in Damascus also a cemetery named after him (maqbarat al-raslaniyya), on the east side of the city. He himself is buried in a well-known mausoleum (turba) outside the Thomas Gate (Bab Tuma), east of the city. There can be no doubt that the fact that he was buried there prompted many local residents to build their homes in his vicinity, since he was known as a miracle worker and as a helper to the needy, as noted in various books on the 'virtues of al-Sham'. As a result of the fact that so many people decided to build their homes near this shrine, the neighbourhood came to be part of the city of Damascus from the Ayyūbid period, when the shaykh died.

From the preceding discussion it become clear that how a shrine can bring about the emergence of a whole neighbourhood, and may lead to the identification there of a tomb bearing the name of the prophet or saint in question (al-Nu`aymi 1990; Ibn `Abd al-Razzaq 1995; alBusrawi 1998; al-Nabulsi 1998; Meri 2001 \& 2002 ). Al-Nu'aymi mentions numerous mausoleums that are named after the person buried in them whether being religious figures, prominent social or political figures, or wealthy men of Damascus, especially in the Mamlūk and Ottoman periods. Thus, for example, the turba (mausoleum) called al-Jamaliyya al-Misriyya, next to the Umayyad Mosque, is named after the judge Jamal al-Din Abu Muhammad al-Misri (d. 624/1226), while the al-Khattabiyya mausoleum, at the foot of Mt. Qasyun, is named after a wealthy shaykh named 'Izz al-Din Khattab b. Mahmud al-'Iraqi (d. 725/1324) (al-Nu`aymi 1990).

Of the Sufi shaykhs al-'Assali can be cited as an example, who was a leader of the Khalwati order (d. 1095/1683), and was buried in a mosque that bears his name, Jami' al'Assali, constructed by the Ottoman governor of Syria. Eventually an entire neighbourhood of 
Damascus came to be called al-Assali, located near the village of al-Qadam, in the south of Damascus (al-Nu aymi 1990). The Sufis, as is well-known, possessed cloisters and cemeteries of their own since the Mamluk period, which in turn attracted residents since the fourteenth century, so that these shrines eventually evolved into neighbourhoods of the city. In several books of the 'Pilgrimage to Syria' one finds names of those who are buried in these cemeteries (al-'Adwi 1956). In a number of sources there is mention of a neighbourhood of Damascus named 'The Sufi Cemeteries' (Maqabir al-Sufiyya), in the south-eastern part of the city.

\section{Al-Shuhada'}

It is a neighbourhood named after the 'Martyrs' graves' (qubur al-shuhada'), located within an ancient village by the name of Arza. It was populated by Arabs since the Muslim conquest and experienced an expansion beginning in the tenth century CE. The name 'martyrs' may refer to brothers, Companions of the Prophet, who were killed during the attack on Damascus by the non-Muslims. The Shaykh Muhammad b. Qadidar (d. 830/1426) constructed a mosque next to their graves and named it after them. Today the neighbourhood by that name is located on the Salihiyya Road, to the north of the Old City of Damascus (al-'Adwi 1956). The neighbourhood has been known by that name since the Mamlūk period. At first it appears to have been a place of recreation, and only evolved into a residential neighbourhood in Ottoman times.

A place does not necessarily have to be holy in order to evolve into a city quarter. Thus, for example, the Hayy al-'Imara (Neighbourhood of the Edifice) in the northern part of the Old City of Damascus is ascribed to a judge of the Mamluk period, Shams al-Din Muhammad al'Ikhna i (d. 816/1413), who built an 'edifice' there. The neighbourhood has two parts, one outside the wall, called al-Imara al-Barraniyya (The Inner Edifice), and the other inside the wall, called al-'Imara al-Juwwaniyya (The Outer Edifice) (al-Nu`aymi 1990; Sauvaget 1932). Also another neighbourhood in Damascus called al-Dardah can be found. As it is manifest from its name it was called after a traditionist (muhaddith Abu al-Dardah, whose full name was 'Abd alRahman b. Isma il b. 'Uthman (d. 665/1266). Today the neighbourhood is located next to the alFaradis Cemetery, between al-'Imara al-Barraniyya and al-'Uqibiyya, and the cemetery by that name still exists near this neighbourhood. Eventually the cemetery and the neighbourhood were integrated into the northern part of Damascus as the city expanded. In the preceding discussion reference is made to several shrines of various kinds that played a role in the demographic evolution of Damascus and eventually were joined to the original core of the city. Another site that may be mentioned here is "al-Suqiyya", a neighbourhood at the beginning of the al-Maydan Road, to the west of the al-Bab al-Saghir Cemetery, in the southern part of the city. This quarter was founded in Mamluk times and contained a market, a mosque and a bath. Small markets such as this exist in considerable numbers outside the city (al-Nu`aymi 1990).

The expansion of the urban agglomeration of the city of Damascus differed from the urban growth of other Muslim cities such as Cairo or the cities of Iraq in which there were preexisting sites that were revered by Shi'ism, such as al-Najaf, Karbala' and others (al-Musawi 1982). However, the residential neighbourhoods that surrounded the city of Damascus from several directions, especially on the north and on the south, played an important role in the city's urban expansion, not due to environmental or residential factors, as was the case in other cities that arose in medieval Syria or in Europe, but rather due to religious factors, namely towns that arose due to the existence of a shrine at that location, such as was the case of Santiago de Compostela in Galicia, Spain, which attracted and still attracts pilgrims from every country in Europe (Melczer 1993). To conclude, Damascus' urban expansion took place from the outside towards the core, because of the holy shrines that surrounded the city from several sides, in particular the al-Qadam Mosque to the south of the city, the Abu Salih Mosque to the north, the mahalla of Shayky Arslan to the east, and others (Al-Harawi 1953). 


\section{References}

Ibn `Asakir. 'A. 1995. Tarikh Madinat Dimashq. Vol. 2. Beirut: Dar al-Fikr.

Ibn `Abd al-Razzaq. 1995. Hadaiq al-in`am. Damascus: Dar al-Maktabi.

Ibn Tulun, M. MS. Tuhfat al-habib fi ma warada fi al-kathib. Leiden University manuscript, fol. 2r. Or. 2512.

al-`Adawi, Y. 1956. Kitab al-ziyarat bi Dimashq. Damascus: al-Majma`al-'Ilmi.

al-Aybash, A. \& al-Shihabi, Q. 1996. Ma`alim Dimashq al-tarikhiyya. Damascus: Ministry of Culture Publications.

al-Basrawi, A. 1998. Tuhfat al-'anam fi fadail al-Sham. Damascus: Dar al-Bashair.

al-Harawi, ’A. 1953. Al-isharat ila ma'rifat al-ziyarat. Damascus: Institut Français.

al-Musawi, M. 1982. Al- 'Awamil al-tarikhiyyah li-nash'at wa tatawwur al-Mudun al- 'Arabiyyah alIslamiyyah. Baghdad: Ministry of Culture Publications.

al-Nabulsi, 'A. 1998. al-Haqiqa wa al-majaz fi rihlat bilad al-Sham wa Misr wa al-Hijaz. Vol. 1. Damascus: Dar al-Ma`rifah.

al-Nu 'aym', 'A. 1990. Al-daris fi tarikh al-madaris. Vol. 1. Beirut: Dar al-Kutub al-'Ilmiyyah.

Kharisat, M. 1992. Al-tawassu' al-'umrani fi Madinat Dimashq hatta awakhir al-Hukm al-Fatimi libilad al-Sham. Amman: Fifth International Conference on the History of Damascus.

Lapidus, I. M. 1971. Muslim Cities in the later Middle Ages. Cambridge: Cambridge University Press.

Meri, J. 2001. A late Medieval Syrian pilgrimage guide: Ibn al-Hawrani's, 'Al-Isharat ila amakin al-ziyarat', Encounters in confluence and dialogue, Brill VII(1).

Meri. J. 2002. The cult of Saints among Muslims and Jews in medieval Syria. Oxford: Oxford University Press.

Melczer, W. 1993. The pilgrim's to Santiago de Compostela. n.p.: Italica Press.

Sadan, J. 1981. Le Tombeau de Moïse à Jéricho et à Damas. Revue Etudues Islamiques IXL.

Sauvaget, J. 1934. Esquisse d'une historie de la ville de Damas. Revue d'Etudues Islamiques IV: 421-480.

Sauvaget, J. 1932. Décrets mamelouks de Syrie. Bulletin d'Etudes Orientales II(I): 1-52. 